International Sociological Association's XVI World Congress

Research Committee 47: Social Movements and Social Classes.

After 'new social movements':

Emerging paradigms of action and culture

Chair: Kevin McDonald

\title{
The Death of Collective Identity? \\ Global Movement as a Parallelogram of Forces
}

Dr Graeme Chesters \& Dr Ian Welsh

\section{Contact:}

Dr Graeme Chesters

Senior Research Fellow

International Centre for Participation Studies

Dept of Peace Studies

University of Bradford. BD7 1DP.

Tel: 0044 (0) 1274234802

Email: g.s.chesters@bradford.ac.uk

Web: www.ParticipationStudies.org 
A force is applied to another force: They form a parallelogram of forces. They do not cancel one another; they are composed, according to a law. The play among forces is reformist: it produces compromises. But the game is never between two forces, it is among countless forces; the parallelogram gives rise to far more complex multidimensional figures.

(Eco 1986: 249)

\section{Introduction}

This paper brings together a number of theoretical and political interests we have with the concept of global movements and the alter-globalisation, anticapitalist, and social justice movements in particular (Chesters \& Welsh, 2004, 2005, 2006). The argument contained in this paper is that these movements are the emergent outcome of complex processes of interaction, encounter and exchange facilitated and mediated by new technologies of mobility and communication and they suggest the emergence of a post-representational cultural politics qualitatively different from the identity based social movements of the past.

At the heart of this argument is the impetus we perceive from complexity theory (Chesters \& Welsh, 2006), non-representational theory (Tormey, 2006, Thrift, 2006) and the renewal of interest in the politics of Deleuzian Philosophy (Patton, 2000) to think difference as ontologically prior to identity, and to take seriously the theoretical challenges this provides to a politics of representation. This ontology appears to be empirically commensurate with the practice of global movements where opposition to the infinite regress of representation and the valorisation of singularity over collective assimilation have become key characteristics.

This questioning of representation is rhetorically evident in the slogan 'not in my name' which offered a distinctive challenge during anti-war mobilisations during the Iraq invasion, whilst the emphasis upon consensus decision-making in movement mobilisations, the valorisation of 'open space' and the prohibition on people 'representing' political parties within the World Social Forum are also indicative of these practices. We argue that in this context of global movements 'collective identity' approaches, that envisage identity as a resource to be mobilised towards the ends of settling a political claim or grievance (McAdam et al, 2001), are theoretically and empirically unsustainable and, instead, we suggest that the complex interplay of social and material forces brought about through encounters within global movement networks can perturbate political systems in unexpected ways.

We also suggest that the embrace of complexity and contingency and the experimental willingness to risk unanticipated outcomes are very much a feature of global movements: one which necessitates a turn away from the over concentration in social movement studies upon instrumental mobilisation within a clearly defined political field and a turn towards an understanding of movements as producers of new forms of knowledge, experience and subjectivity that are antagonistic precisely because they are irreducible to a political grievance or a minority interest, and instead illustrate an immanent field of potentialities - the other worlds that are possible. 
To this extent our work compliments those stressing the importance of 'knowledgepractices' (Osterweil, 2004) within contemporary movements and it echoes the emphasis upon the materiality of these movements contained in the paradigm of embodied intersubjectivity suggested by McDonald in his description of 'grammars of experience' (2006). However, despite welcoming the return of the so-called 'irrational' to social movement studies - embodied experience (McDonald, 2006), the emotions, culture and affect (Goodwin et al, 2004, Polleta, 2004) - we are keen to preserve a focus upon social movements as potentially generative of antagonistic challenges to capitalist axioms whose logic is to colonise and appropriate experience and knowledge in the production of new forms of value.

However, we locate this potential, not in the capacity of movements to mobilise within a clearly defined social or political field, but in the capacity of movement practices to construct critical subjectivities which can combine with non-linear processes of encounter and interaction to present an 'emergent' challenge to the dominant logic of political and social systems. For this reason we are particularly interested in those spaces where the expression of difference and the opposition to representation are combined with a desire to multiply struggles and develop solidarities, spaces that presume and preserve singularity as difference and experience whilst creating the possibility of emergent outcomes through cooperation and exchange. Drawing upon complexity theory and Deleuzian philosophy we might refer to these spaces as akin to a plane of consistency, or as 'heterogeneity preserving emergent structures' (Bonta and Protevi, 2004:124), but more often we have referred to these spaces as 'plateaux' (Chesters \& Welsh, 2005, 2006).

\section{Plateaux}

In order to transcend the current paradigm of new social movements the main characteristics of recent collective action must be identified. Even though I am not in search of the central movement of complex society, I maintain that there are forms of antagonistic collective action capable of effecting the logic of complex systems.

(Melucci 1989: 73)

In order to analyse these processes, including the formation of critical subjectivities, network interaction and emergent outcomes, we are suggesting a conceptual framework that allows descriptive and analytical purchase over a key process in the emergence of global social movements: the process of encounter and interaction and the process of constructing shared understandings within and between movements that takes place in summit protests and social forums.

One of the most interesting yet under-theorised concepts to arise from those who originally developed the idea of framing as an analytical tool (Bateson, 1972, Goffman, 1974) is the concept of plateau(x), originated by Bateson (1973) and subsequently developed by Deleuze and Guattari in their second volume on Capitalism and Schizophrenia (2002). Plateau has geological, mathematical and figurative meanings, but was used by Bateson to differentiate a preference within Balinese culture for the continuation of intensity over the transcendence of culmination or climax, an orientation that he noted as extending from sexuality to aggression. Deleuze and Guattari (2002) developed this concept as an extension of 
their distinction between arborescent culture (linear, binary, hierarchized) and rhizomatic culture (multiplicitous, heterogeneous, non-linear): "We call a "plateau" any multiplicity connected to other multiplicities by superficial underground stems in such a way as to form or extend a rhizome' (Deleuze \& Guattari 2002: 22).

In our formulation we use plateau(x) as a descriptor for the process of intensive networking in material and immaterial spaces that occurs around nodal points of contestation or deliberation, such as protest events or social fora. This allows us to focus upon processes of territorialisation - the manifestation of networks within physically and temporally bounded spaces and lines of flight between territories - the reconfiguration of networks through processes of encounter, the proliferation of weak links, the exchange of knowledge and the construction of affective relationships through facework and co-presence. These processes of physical interaction that characterise global social movements - the protest actions, encuentros and social fora - are further understood to be dynamically interconnected and co-extensive with a digital commons ${ }^{\mathrm{i}}$ that underpins computer mediated interaction and communications and which co-constructs the rhizomatic formation of the alter-globalisation movements (AGM). This rhizomatic 'network of networks' (Melucci 1996) constructs 'new' democratic spaces for deliberation on complex global problems and frames these problems within the discourse of 'anti-capitalism' and 'alter-globalisation'. These participatory fora, including the conferences and gatherings of People's Global Action (PGA), the World Social Forum (WSF) (Fisher $\&$ Ponniah 2003) and its regional sub-conferences, are central to the emergence of global social movement networks as antagonistic actors within global civil society.

These encounters facilitate the elaboration and exchange of diverse perspectives, emerging from specific histories and cultures of struggle, which fuse with desires to explore the potential of synergistic forms of collective action that can retain diversity whilst exerting social and political force. Unpacking the dynamics of these interactions requires an analytic descriptive vocabulary able to address how individual and group interpretive schemas are constructed, represented and changed within plateaux. Social movement theory has traditionally used 'frame analysis' as a means of engaging with such processes. Whilst we continue to utilise a frame analytical approach, the concept of plateaux and the centrality of network actors reorients the object of frame analysis underpinning Goffman's (1974) formulation. For Goffman, the object of 'frame analysis' is a 'strip of activity' arbitrarily selected by an individual and subject to sense-making activity. This results in a discussion of individual reflexivity 'too removed from fieldwork' (Goffman 1974: 10).

Our use of plateaux departs from Goffman's notion of a strip of activity in two important ways. Emphasising fine-grained fieldwork, using multiple recording techniques that were unavailable to Goffman, we have previously analysed how individual frames can become group frames within particular movement events (Chesters \& Welsh 2004) and this work suggests that plateaux are typically longer than the notion of a strip suggests, creating multiple event horizons that persist long after the particular event is 'over' (Welsh 2004). We use the concept of reflexive framing (Chesters \& Welsh, 2004) to address the iterative process of renegotiating meanings through retrodictive sense making utilising feedback mechanisms including computer mediated communications (CMC); list-serves, web logs and post-event video screenings. This allows us to advance a conceptual framework for 
interrogating processes of iteration at different scales (macro to micro, synchronic to diachronic) across the ebbs and flows of movement activity permitting further insights into processes of capacity building accentuated by relations of affect and intensity inculcated within plateaux:

...a plateau is reached when circumstances combine to bring an activity to a pitch of intensity that is not automatically dissipated in a climax leading to a state of rest. The heightening of energies is sustained long enough to leave a kind of afterimage of its dynamism that can be reactivated or injected into other activities, creating a fabric of intensive states between which any number of connecting routes could exist.

(Massumi, 1992:7)

Thus we conceptualise plateaux as events of temporary, but intensive, network stabilisation where the rhizomatic substance of the movement(s) - groups, organisations, individuals, ideologies, cognitive frames etc - are simultaneously manifest and re-configured. The study of movement plateaux thus requires a focus upon process, interaction and intensity. The 'object' of analysis becomes the iterative character and fractal patterning of overlapping networks and the processes of interaction and exchange between global locales, the relationship between the virtual and the real, and the interaction between new social actors and familiar forces of antagonism.

Understood this way, plateaux provide a reflexive impetus for movements: an opportunity to recognise 'oneself' and the points of connection between one's identity and actions and those of other participants engaged in similar struggles. They also allow for the expression and exploration of difference (identity, politics, strategy, goals) through theoretical and practical innovation. This includes cognitive and symbolic re-framing (Chesters \& Welsh 2004) and the construction of distinct spatialities within the one temporality (e.g. dedicated action zones for different protest repertoires, or autonomous spaces within a social forum).

Interaction of this sort encourages the formulation and shaping of political projects at local and global levels and enables strategic and tactical reflection. Other outcomes include the transmission of 'techniques of self' conducive to collective expressions of solidarity and mutual aid. Plateaux are therefore increasingly the means through which phase transitions occur in movement forms; they precipitate increases in flows of energy, which produce non-linear changes in the system (of relations) conducting that energy. These can include anything from a mundane re-orientation of campaign focus, to changes in the internal dynamics of decision-making within a social movement organisation, or the wilful 'contamination' of leftist parties seeking greater purchase amongst social movement actors.

The World Social Forum and its regional offshoots are one of the most tangible expressions of movement plateaux, eulogised by Hardt and Negri as 'a new democratic cosmopolitanism, a new anticapitalist transnationalism, a new intellectual nomadism, a great movement of the multitude' (2003: xvi). This space of encounter was strongly influenced by ideas expressed during the Zapatista Encuentros (encounters) of the mid-90s, where the concept of creating a global 'mirror and lens' (collective recognition and focus) for antagonistic movements was first elaborated 
(see Marcos 2001). This process enabled activists to 'bridge worlds' through the deliberate construction of spaces wherein links between diverse movements could be made.

The importance of 'weak ties' and 'social bridges' for the elaboration of communication and access to resources is familiar from Granovetter's (1973) work on the 'strength of weak ties' and latterly from those elaborating theories of small world networks (Barabasi 2002, Buchanan 2002). This counter-intuitive argument suggests that it is the weak ties between people, not strong friendships, that are most important when it comes to such things as launching a new project, finding a job, and accessing news. This is because weak ties are crucial for being able to communicate beyond one's immediate social (or activist) worlds. Close friends and fellow activists almost inevitably move in the same circles and, as such, are most likely to be exposed to the same information. Weak ties have to be activated to open new channels of information and maximize potential for agency - ties which might include e-mail contacts, people met during meetings, at protests, and during gatherings. There is also a need to be able to connect with those activist hubs individuals active within many networks ("spiders at the centre of many webs"ii), networking spaces (such as forums and information exchanges), and social centres without undue interference from structures and hierarchies, or barriers to participation, such as class, culture, age, gender, and race that would inhibit such connections.

It is this combination of elements: large numbers of interacting individuals, groups, and movements constituting an open system, that adapts to its environment leading to increased reflexivity facilitated by feedback loops and non-linear processes of interaction and iteration, that in turn leads to even greater complexity. Plateaux are combinatory expressions of complexity effects realized through assemblages of material and immaterial elements. They are shaped by the material infrastructure of mobility and communication systems that are a pre-requisite of a "network sociality" (Wittel 2001), and through their emphasis upon co-presence, face-work, meetings, and encounters, they point to how these material assemblages realize the potential of small world networks. What emerges is a network of networks, increasingly shaped by an eclectic mix of minoritarian subjectivities, of virtuosi, including net-workers of various kinds - artivists, hackers, mediatistas, and academivists (Notes From Nowhere 2003) - whose capacity to resist co-option by party discipline and ideological strictures is growing as a direct result of increasing complexity.

\section{From Plateaux (Plane of Consistency) to Parallelogram of Forces}

Through the artisanal creation of new knowledges and critical subjectivities, plateaux can facilitate the multiplication of forces in subjective, material and symbolic domains with the resultant vectors expressing both force and flight, thereby exposing the prevailing capitalist axiomatic of neo-liberalism to challenges that cannot be met by the application of equal and opposite forces within the fashion of a hegemonic struggle. This 'asymmetric' challenge is frequently addressed by political elites through the application of 'simple' solutions, including violent intervention by the state, such as the pre-emptive attacks against protesters in Genoa at the G8 protests in 2001, or populist attempts at assimilation through global governance structures. ${ }^{\text {iii }}$. In this section we explore the force relations within this field of struggle by developing our account of the antagonistic potential of the alter- 
globalisation movements (AGM) and further distinguishing the composition of relations and forces constituting this movement(s), by explaining how collective identity approaches to social movements are problematised by the emergence of a global movement milieu animated through plateaux.

We argue that, through plateaux, global movements are able to hold in dynamic tension the expressive and transformative potential of a number of ideological and discursive traditions, not as an integrated collective identity but as a parallelogram of forces that enables the realisation and multiplication of force relations through the exploration and actualisation by the AGM of virtual singularities (Protevi 2001: 610) - immanent possibilities present within global civil society (Chesters, 2004).

It should be clear that we use the term parallelogram of forces in a distinctive way which is designed to achieve two ends, the first is to recognise antecedents in Marxist theorising on the potential of force relations (Engels, 1955, Althusser, 1962, Bensaid, 2002), whilst the second is to indicate the limits of this linear model of aggregation and causality for our study of global movements. Our 'parallelogram' is akin to that which Umberto Eco first portended when he described 'the game... among countless forces' where 'the parallelogram gives rise to far more complex multidimensional figures. This we suggest is a metaphorical prefiguration of the concept of emergence ${ }^{\text {iv }}$, a key feature of contemporary work in complexity theory (Urry, 2003, Chesters \& Welsh, 2006), which suggests that the interplay of such forces provides the potential for extraordinary and unanticipated outcomes, which we struggle to understand or predict.

Indeed sociology and the social sciences more generally have a remarkably poor record in terms of understanding the dynamics of, let alone predicting, significant social change. Social movement and historical scholarship demonstrates that significant shifts in normative thinking and behaviour frequently originate in the liminal spaces on the social, cultural or geographical margins (Alvarez et. al. 1998, Kenney 2003, Stephens 1998). The problem has been, and remains, identifying the marginal vectors with transformatory potential within the prevailing set of material circumstances and conflicts. In terms of the themes we have engaged with, there is no consensus over these conditions but some key elements are arguably clear. Amongst these, the significance of networks and the primacy of mobilities, encounters and knowledge practices in a global age stand out as key examples (Melucci 1996, Castells 1996, Hardt \& Negri 2000, Urry 2000, 2003).

These accounts typically share an analytical focus upon the rise of computer-based communications, the transition to knowledge economies and the significance of 'sign values' (see Lash \& Urry 1994). Hardt \& Negri argue for the increasing importance of 'immaterial labour' producing services, 'cultural product, knowledge or communication' (2000: 290). Their analysis emphasizes that such 'affective labour' is a collective production of 'social networks, [and] forms of community,' (2000: 293). Our interrogation of plateaux suggests that this resonates with the production of a cultural politics, rather than a political culture, and the creation of a 'new type of resistance' such as that envisaged by Hardt \& Negri (2000, 2005). Just as cultural forms have suffused products and brands (Klein 2000) they are affecting the 'political' by rendering visible and declaring global stakes - namely that 'what is at stake is life itself' (Hardt \& Negri 2000: 313). Inverting this we could also say 
that the AGM has rediscovered the project of political life to be immanent to the style in which one lives (Bogue 2004: 9-26, Deleuze \& Parnet, 2002: 127-128). In this sense there is an articulation of the need to 'live in truth' at a global level, recognising that the threat to life posed by Hardt and Negri includes both the material conditions of physical existence and the anatomy of the human subject in an age of genetic modification.

We broadly agree with Hardt (2002) that one of the central tensions within global civil society lies between those advocating a renaissance of the nation-state as a political bastion against capitalist globalisation and the antagonistic orientation to challenge all forms of capitalism and centralized political representation. However, our conception of this dynamic differs in a crucial respect with significant methodological implications. By approaching protest events as plateaux, rather than one of many 'nodes in its indefinitely expansive network' (Hardt 2002:118), we are preserving the integrity and centrality of rhizomatic forms. Network analyses sometimes reproduce a cartographic form of engagement within social science that seeks to map networks, measure densities and so on. Networks are depicted as if they are bounded conduits connecting discrete actors with specific grievances and aims intersecting within equally bounded 'nodes'. This approach faces the cartographic contradiction dating from Aristotle namely that it is impossible to draw a map of the world on the world.

The rhizome metaphor does not just stand for non-hierarchical forms but also reflects the multi-layered diffuse and interactional nature of the processes through which rhizomes constitute and shape 'forceful bodies': the 'particular force arrangements of chemical, biological and social bodies' (Protevi 2001:3). When understood radically, this distinction allows us to move beyond the reductive aspect of network analyses, which are prone to emphasise connectivity over the capacities for material self-ordering arising from such connectivity and the force arrangements that emerge from these processes. This is consistent with the argument advanced by Deleuze and Guattari and articulated by Protevi (2001, Bonta \& Protevi 2004), who suggests that 'questions of human freedom are only explicable when we address emergence above and below the level of the subject' (Bonta \& Protevi 2004: 35).

The increasing potential for 'free acts' within complex systems (Eve et. al. 1997: $\mathrm{XV})$ requires attention to the experiential degrees of freedom through which individuals subjectively experience, recognise, modulate and replicate libratory repertoires of self. This might include anything from exercising constraint upon the autonomic nervous system through to perturbating social, cultural or institutional constraints inhibiting emergence. In this way, the extensive creation of a rhizomatic movement through plateaux is an experiment, in the pre-subjective, subjective and collective invocation of singularities cooperating to express difference, not the assimilation and integration of difference within the constraints of a collective identity that subsequently claims to represent some fabricated whole.

Whilst mapping the networks is analytically useful, it is important not to equate such maps with 'the movement' as this merely reproduces the reification the term social movement has been accused of. As Hardt's own account of a World Social Forum (WSF) meeting attests, it was 'unknowable, chaotic, dispersive' due to the huge penumbra of 'weak' actors and their sprawling networks. In terms of our work, the 
notion of 'serendipitous entrants' (Welsh 2002) and the mapping of the impact of one such entrant upon the framing and force arrangements occurring within the Prague plateaux (Chesters \& Welsh, 2004) is an empirical illustration of this phenomenon and an example of a methodology we designed to address it.

\section{Collective Identity, Identity Politics, Identization}

Whilst collective identity is ontologically and empirically problematised by global movements, it is not without analytical purchase when formalised by Melucci (1996) as a form of process metaphysics, albeit this raises a number of further issues. Many commentators have remarked upon the 'unity in diversity' that is characteristic of the alter-globalisation movements, most celebrated in the 'Teamsters and Turtles' united in Seattle (Berg 2002). Behind such rhetorical formalisations lies the interactive 'reality' through which a constellation of contingent factors are configured as unity through an iterative negotiation and intercession, which can only be revealed through rigorous empirical and analytical work of a genealogical nature.

The potential for unified collective action constructed by a diverse range of social actors is, of course, implicated in analytical formulations of the term social movement (Melucci 1980, 1981, Diani 1992: 13). However, as Melucci (1996: 187) notes, the tendency to conflate the concept of a movement and the discursive category of 'identity politics' is widespread. This, as Melucci (1996: 187-188) argues, is why the concept of collective identity should be separated for analytical purposes from the idea of 'identity politics' and underpins our questioning of the very basis of collective identity formulations.

The rise of interest in collective identity formation paralleled the decline in interest in Hegelian/Marxist conceptions of social change as the capital/labour axis began to be regarded as less important in understanding social dynamics in 'post-industrial' (Bell 1973), 'programmed' (Touraine 1971), 'information' (Castells 1996) or 'complex' societies (Melucci 1996). This was reinforced by the claims and actions of those who had previously been conceived as marginal social actors: women, students, ethnic minorities, young people, gays, lesbians, and the unemployed. This in effect constituted the modern sub-disciplinary domain of new social movement studies as a theoretical and empirical endeavour (Melucci 1996, Diani \& Della Porta 1998, Tarrow 1998, McAdam et. al. 2001). Here, despite Touraine's (1981) attempts to construct a conception of society based upon a praxis of social conflict undertaken by movements, there was a notable decline in discussion of how diverse groups might unify to form antagonist movements at particular historical junctures.

For the purposes of clarity, we define 'identity politics' as the pursuit of political recognition for aspects of social and cultural specificity arising from one's particularistic identity based upon gender, sexuality, ethnicity, disability, age and so on. These are akin to what Castells (1997: 8) refers to as a 'resistance identities' generated by actors who are repressed, stigmatised or devalued by the structure of domination in a given society. Other commentators have noted how these identities are often manifest as a politics of difference and cultural hybridity (Lash and Urry 1987, 1994, Rutherford 1990, Featherstone 1991), and still others have addressed the problematic nature of theorising particularistic identities (hooks 1981, Haraway 1989, Appiah 1992, Butler and Scott 1992). 
We argue that global movements consist of a number of analytically distinct social practices and forms of action, which connect deterritorialized elements of the social field in a given historical and political context. Thus, 'identity politics' can be an integral aspect of the social practice of a movement, without the movement being reducible to it. Melucci (1996: 70) defines collective identity as the process of constructing an action system. This identity is not static or fixed, but remains continuously in motion, requiring active identity-work, even where it crystallises into semi-permanent institutional forms. Melucci calls this process 'identization' (1996: 77) to delineate the orientation towards solidarity over solidity and the iterative process of renegotiation that occurs in social movement networks.

Therefore, the Meluccian concept of collective identity presumes the self-reflexive capacity of social actors to recognise themselves and the field of opportunities and constraints (environment) in which they are situated. However, the term 'identity politics' is often used as a discursive means of describing a set of empirical actors for whom the analytical distinction between political engagement and identity has been attenuated. Melucci (1996: 187-188) suggests that this is because political engagement with established institutional actors requires a reduction of the multidimensionality of the issue at stake; a process which foregrounds substantive demands and grievances subordinating identity issues (Welsh 2000: 226). This frustrates the potential of the associated identity claims increasing the potential for movement dis-unity as 'identity wars' break out inside the movement milieu. This paradox is not easily resolved within the narrow means of political engagement with institutional frameworks:

The issues they raise are inextricable from the problem of how difference can be accommodated in a differentiated society, in which both of the two horns of the dilemma must necessarily be kept together: a differentiated society can function only based on the acknowledgement and valuation of differences, but, at the same time, the increased differentiation of the system calls for a proportionate intensification of its mechanisms for integration

(Melucci 1996: 188)

Consequently, in institutionalised politics differing marginalised and oppressed groups are forced to compete for political mediation and representation by seeking the extension of integrative mechanisms within representative democracy to realise minority claims. However, particularistic identities can also find parallel means of expression through extra-institutional forms manifest in a range of social and cultural realms simultaneously coexistent with and constitutive of social movement networks, some of which leads to antagonistic collective action. This is an important distinction precisely because such actions can hasten the process of 'becomingminor' in the Deleuzian sense (2002: 104-106). The process of unfolding culturally sedimented potential as political action, by accentuating the gap between subjectivity and normative order, intersects with the 'paranoid' dynamic of capital towards reterritorialisation of 'minority' claims within institutional frameworks, reducing them to 'special interests' or niche markets based upon a fixed concept of identity.

This dispersed, hybridised culture of diffuse engagement along cultural and political fault lines could lead one to reject the possibility of unifying struggles which are 
capable of addressing Melucci's (1996: 188) 'dilemma': struggles in which social movement organisations and networks recognise the difficulties and tensions of negotiating 'unity', yet remain able to mobilise diverse constituencies around a meta-identity or protest theme. Melucci's (1996: 40) development of a typology of social movements sensitises us to the role of 'ends', 'means' and 'environment' in structuring such social movement activity. This typology also allows us to indicate the level at which social movements threaten the internal variability of the systems they seek to challenge, defined as the limits at which a system can no longer assimilate the movement's demands or the forms of action it employs. In Melucci's (1996) model of complex societies, these systems include the cultural sphere of the 'lifeworld', the administrative and organisational systems, the political system, and the system of production, distribution and exchange of crucial social resources (capitalism).

Theoretically, then, Melucci (1996) illustrates how 'identity politics' as a form of social practice within social movements may discursively invest and perturbate a variety of different systems, often paradoxically through the development of a mutable concept of identity. Such social practices might cause legislative changes, facilitate cultural experimentation and result in a host of differing outcomes for their participants. Despite the centrality of such forms of expression to social movement activity, this does not mean that the potential of social movement networks are reducible to it. The crucial question for Melucci remains:

Are contemporary movements capable of bringing about social and political change or are they simply reducing collective action to expressive and "narcissistic" celebration of the particularism of identities?

(1996: 185)

This is also a rhetorical question framed by Melucci to retain a focus upon the orientation of movements and the systemic levels they address/articulate/affect or perturbate. Despite its rhetorical formulation this question remains critical because it is frequently deployed at the political level as an argument for forging collective identity via party mechanisms and at the theoretical level as a riposte to those broadly perceived to be within the postmodernist cannon, including Deleuze and Guattari (2002). However, this charge misses Deleuze and Guattari's distinction between minor, minority and minoritarian (2002: 104-106), which informs our understanding of the emergence of social force within the AGM through the process of 'becoming-minor' effected by the circulation of struggles in plateaux:

The notion of minority is very complex, with musical, literary, linguistic, juridical and political, references. The opposition between minority and majority is not simply quantitative. Majority implies a constant, of expression or content, serving as a standard measure by which to evaluate it ...A determination different from that of the constant will therefore be considered minoritarian, by nature and regardless of number, in other words, a subsystem or an outsystem ... That is why we must distinguish between: the majoritarian as a constant and homogenous system, minorities as subsystems; and the minoritarian as a potential, creative and created, becoming.

(Deleuze and Guattari 2002: 105-106) 
This becoming is immanent to plateaux where the artisanal "under-labourers" cultural work - deliberation, negotiation, symbolic exchange, identity construction and affectivity - supersedes the hylomorphism of prescriptive party organisations, and is processualised through weak ties and spaces of encounter, multiplying the possibility of combinatory forces. Both Melucci (1996) and Deleuze and Guattari (2002) recognise that the multiplicity of possible modes of engagement within differing systems of complex society leaves open this potential and as such they distance themselves from the assumption which contends that a politics of difference and cultural hybridity (Lash \& Urry 1987, 1994, Rutherford 1990, Featherstone 1991) marks an end to political projects that are expressed antagonistically. Rather, as we have shown, political projects that emerge in social movements do not have to be built upon particularistic identities, although they may contain characteristics that can be expressed by the term 'identity politics'. Equally, transgressive identities that rest upon cultural practices are not only performative and expressive (Hetherington 1998), they may also contain within them orientations that are antithetical to the prevailing system of production, distribution and exchange, and therefore produce/reconfigure the phase-space of mobilisation re-introducing valency with other antagonist actors. Consequently, Melucci's typology of social movements (1996: 34-35), combined with the detailed empirical exposition of the formation of an antagonist orientation in social movement networks, sensitises us to the possibility of philosophically coherent, unified and 'minoritarian' political projects emerging from amongst the empirically observable diversity of global social movement networks $\mathrm{v}$.

\section{Lines of $F(1)$ ight}

The word flight is often abused and at any rate carries dangerous connotations. Flight does not mean necessarily an escape into some mythical outside free from social conditioning. It is rather a moment of active creation of autonomous spaces within the existing order. Flight enables you to try and elude the status quo which subjects individuals to its political power and thereby defines their spatial movement.

(Viano and Binetti 1996: 252)

There is no need to fear or hope, but only to look for new weapons

(Deleuze 1995: 178)

A complex outcome of the parallelogram of forces constituted by the AGM and the play of those forces within movement plateaux has been the production of powerful symbolic challenges that resonate beyond their immediate participants or anticipated constituencies. Examples of these processes include challenging the legitimacy of the global institutional nexus (WTO/IMF/World Bank) and the global anti-war demonstrations on 15 February 2003, initially proposed at the Florence European Social Forum meeting in 2002.

Given the unpredictable outcomes and multiplier effects of movement plateaux it is reasonable to ask about the model of social change that emerges from the concept of global movement as a parallelogram of forces and how we can gain analytical purchase over agency and organisation in complex systems. This requires us to examine differing vectors, the resultant force-combinations and emergent properties that are manifest in protest events and symbolic challenges in specific space-times, 
and the lines of flight represented by experiments in the creation of autonomous spaces, cultural production and radical subjectivities best described by the Deleuzian concept of 'becoming-minor'. Deleuze $(1994,2002)$ suggests the importance of material self-ordering within complex systems whilst retaining a pragmatic emphasis upon intervention, upon agency as immanent structuring, and ethics as a means of experimentation within a 'body-politic'.

As Bogue has shown, Deleuze systemises Foucault's thought by 'establishing the relationship between the archaeological strata of knowledge, the genealogical domain of power and the ethical folds of the self' (2004: 53). Deleuze locates the ethical self as a locus of resistance to the systematicity of knowledge-power processes and the starting point for the task of exploiting the interstices in those systems so that the reproduction of control can be traversed or subverted. Moreover, he situates those ethics in a broader process of becoming-minor that has relevance for the post-representational politics of the AGM.

In Foucault's genealogies of disciplinary control (1975, 1977, 1979), his 'histories of the present', he describes a system of power that becomes ever more complete through the extension of disciplinary institutions and discursive, linguistic and symbolic formations that regulate and order life. Deleuze (1992) takes this further in his 'postscript on societies of control' arguing that the pervasive character of technology and disciplinary logic allows for the dispersal of control mechanisms throughout society, so that we are now subject to continuous monitoring through the modulation and extension of formerly spatially bounded institutional logics. The socio-spatial discipline provided by schools, factories, hospitals and prisons are replaced by technologically mediated and 'virtual' enclosures - 'life-long' learning, corporatisation, risk assessment, 'performance' management and the universalised panopticon of the 'invisible', immaterial prisons constructed by CCTV, electronic tagging, bio-metric identity cards and house arrest. These forms of control find local and global expressions and have developed in parallel to the extension of systems of governance to the global level, the integration of financial systems, and the liberalisation of capital flows to form what Guattari (2000: 47) calls 'integrated world capitalism' and what Hardt and Negri (2000) describe as 'Empire'.

Against this, Deleuze (1988) sees in Foucault's ethical studies the possibility of 'the self as a locus of resistance, a point at which thought itself can become a political force' (Bogue 2004: 53). Resistance is located in the rejection of 'habits of mind' (Bateson, 1973) associated with the 'common sense' constructed through the dispersed logics of control and the formulation through encounter of an ethics of invention and intensity rather than a moral politics. Deleuze suggests that the entropic tendency of force towards dispersion and disorganisation can be accelerated through minoritarian becomings, leading to the deterritorialisation of key elements of the social and political field. This is not, then, a personal ethics, but a knowledge practice based upon what Massumi (2002: 255) calls 'symbiosis tending' the bringing together of diverse elements in ways which allow them to escape the reductive imposition of a unitary standpoint or identity.

The 'schizophrenic' tendency of capitalism identified by Deleuze and Guattari (2002) ensures ever-greater differentiation and the subsequent elevation of difference as the generative dynamic behind informationalised production - new 
styles, objects, modes of exchange - creates both opportunities and pitfalls for further experimentation. In this context, plateaux allow lines of flight constructed locally in the spatio-temporal dynamics of protests and sub-cultural experiments, to be multiplied globally resulting in force-combinations that act against specific sites and manifestations of the neo-liberal axiomatic through the ethics and practices of a 'coming-together' (Massumi 2002: 255) which valorises affectivity, deliberation and consensus. Examples of this include the use of street parties as protest repertoire (Jordan 1998), carnival as a cultural analytic, and the symbolic multiplier effect of participatory practices from participatory budgeting in Porto Alegre (Bruce 2004) to non-representational decision-making in the Zapatista 'Caracoles'. These experiments transcend the local and are diffused globally as both force and flight, they are increasingly the exodus of those who 'flee but whilst fleeing seize a weapon' (Deleuze \& Parnet 2002: 136).

\section{Thought as weapon and attractor: Intellectual deterritorialisation}

So far we have argued that the parallelogram of forces is composed of material, symbolic and discursive aspects which allow for the emergence of molecular lines of flight and force combinations that are catalysed by the AGM's capacity to access virtualities present in global civil society (Chesters, 2004). If as Bogue (2004) suggests, Deleuze's reading of Foucault posits the self and thought as a locus of resistance then we must also ask the question of how this resistance maps between the individual and the collective and in what contexts and through what knowledgepractices this resistance becomes more or less likely. We have already demonstrated the importance of overcoming the majoritarian 'habits of mind' that Bateson (1973) identified and the 'dogmatic' image of thought criticised by Deleuze for its purely representational perspective (see Patton 2000: 18-23). However, we must also clarify the scope of what Deleuze means by 'thought' and reconsider how this relates to individual agency and collective action in the light of new mobilities and technologies, proliferating 'weak ties' and the emergence of complex global movements.

To live and think differently is intensely difficult and as Deleuze admits, minoritarian becomings are rarely individual. However, the possibilities for connecting to others through new patterns of communication, interaction and mobility have never been greater. These new topologies of social relations increase the range and space for thinking together and enable the circulation and iteration of minoritarian ideas and perspectives, affirming the possibility of lines of flight from orthodox understandings and generating emergent knowledge-practices based upon collective reflection, iteration and critique. This encourages intellectual deterritorialisations, the appearance of new concepts (attractors) and subsequent reterritorialisations, as these attractors become practices: a collective process and a thinking-through action that has given rise to creative concepts, some of which are systemised as a means of temporarily stabilising debate and reflection. Consequently, knowledge-practices serve constitutive and explanatory ends within movements providing suggested trajectories and enabling forms of feedback that can multiply expressions of either force of flight. The most obvious examples here are those of 'Empire' and 'Multitude' proposed by Hardt and Negri (2000, 2005), however there are other theoretical constructs that emerge from similar traditions that are also worthy of further examination because of their sensitivity to the rhizomatic, informationalised and cultural politics of the AGM. 
For example, one way of envisaging the potential of flight and force combinations explored by the AGM is through the concept of exodus originally developed by the Italian 'workerist' movement (Operaismo) and subsequently articulated by Virno $(1996,2004)$. This concept provides a powerful metaphor through which to describe the lines of flight that can actualise the immanent qualities of the virtual field created by new forms of material and cultural production. As we go on to argue there is a need to redress the over-emphasis upon labour processes and the deduction of a 'subject' of revolution from economic and class analysis in the work of both Hardt and Negri. Whilst Virno's analysis shares many of the same 'workerist' tendencies, the symbolic power of exodus is its capacity to communicate the seemingly paradoxical idea of flight and/as force. Exodus recalls the refusal of work thesis that has found expression from Mario Tronti's 'Strategy of Refusal' (Tronti 1966, Wright 2002) to the Situationist exhortation: 'Ne travaillez jamais', it evokes the nomadic resonances of asignifying movements familiar in Melucci (1996) and echoes the Deleuzian concept of 'absolute deterritorialisation'. Wherein a system is moved past a critical threshold allowing new bifurcators and attractors to emerge through the accleration of intensity enabled by the 'connection of flows' (Deleuze and Guattari 2002: 220). For Virno (1996: 196) exodus requires the 'institution of a non-State public sphere' (GCS) through a cultural politics that develops the 'publicness of intellect' in opposition to the capitalist axiomatic. .

Workerism in the Italian tradition has then, somewhat heretically given other Marxist traditions, sought to avoid the reduction of life to work, and instead valorises the creative capacities of labour for self-organisation against capitalist production processes rather than within them. The extension of this current to include the 'new social subjects' in the late 1960s and the re-thinking of the centrality of the proletariat within Marxist class analysis by prominent young intellectuals such as Sergio Bologna, Mario Tronti, and Toni Negri (Lotringer \& Marazzi 1980, Wright 2002) led to the replacement of Operaismo by the broader movement of Autonomia, a movement that shook the cultural, economic and political foundations of Italian society in the mid-1970s (Wright 2002). The rhizomatic organisational forms that characterised Autonomia and the active participation of women, students and the unemployed, combined with a strong bias towards social and cultural activity, provided a vivid experimental context in which to explore afresh the dynamics of social struggle. This brought together Italian autonomists and radical French philosophers in the mid-70s including Negri and Deleuze initiating the intellectual trajectory resulting in Hardt and Negri's work (2000, 2005), and stimulating an avid interest in a previously marginal and still 'minor' intellectual and revolutionary tradition.

This tradition provides an interesting lens through which to examine some suppositions and differentiations in conceptual attractors that are animating the AGM, specifically the contemporary salience of Hardt and Negri's (via Spinoza's) category of Multitude (2000, 2005). Virno draws attention to Hardt and Negri's rejection of the 'hybrid thesis', the idea that capitalism can be as simultaneously creative as labour, rather he argues in a similar vein to Deleuze and Guattari (2002) that capital is mutable, inventive and creative as well as destructive. Lotringer (2004) thus argues that Virno is presenting a description of combat, 'a cartography of virtualities made possible by post-Fordism' where one is 'meant to strengthen 
some forces present in capital and join them with other forces to form a new communist ensemble' (2004: 16-17).

Opposed to this is the tendency to reconstruct Multitude as both the sustaining and productive force of Empire and the source of its ultimate demise which as Lotringer notes, places Hardt and Negri's telos before Multitude. The intellectual line of flight taken by Virno's conception of multitude (2004) and the political theory of Exodus (1996) is more Deleuzian and more sociological. Whilst it is full of pragmatic considerations, including points of intervention in and sensibility to the subjective and collective insecurities, hopes and fears created by informationalised capitalism, it also embraces the subsequent projection of self and community into a continuous relationship to the other. In this context, Virno suggests the crumbling concept of a people secure behind the walls of community and representing the unified subject of the state, can be contrasted with the sense of 'not feeling at home' that results from transverse lines of communication, interaction and affect experienced by the Multitude. Whilst the generalisation to the public sphere of this feeling is a precursor of multitude, it also creates space for 'molar' reterritorialisations (Deleuze \& Guattari 2002:40, 335), the return of vectors tracing themes of terror, racism and war, to which multitude must respond.

Virno's (1996) political theory of Exodus provides a framework for examining the establishment of this context and a prescription for how the Multitude might respond. He demonstrates how lines of flight traverse movement milieu connecting practices of resistance to the broader dynamics of social and economic systems, including the post-Fordist reorganisation of production and the centrality of communication and 'performance' within an informationalised global economy. Virno argues that 'post-Fordist' methods of production result in the absorption by the labour process of the key attributes of political action. Therefore novelty, unpredictability, creativity, communicative networks, and linguistic 'performances', all become characteristics of information-orientated production that assumes 'actionist' traits ${ }^{\mathrm{vi}}$. Virno (1996) argues that work has colonised the sphere of the 'general intellect', using 'general social knowledge' to service an economy that is reliant upon the production and processing of knowledge and information:

In any case, what other meaning can we give to the capitalist slogan of "total quality" if not the attempt to set to work all those aspects that traditionally it has shut out of work - in other words the ability to communicate and the taste for action?

(Virno 1996: 193)

This position is not unlike the position taken by proponents of the 'reflexive modernization' thesis (Beck et. al. 1994), whose central claim is that 'post-Fordist' structures of production require the progressive freeing of agency from structure (Freisetzung). Scott Lash explains this as follows:

Knowledge-intensivity necessarily involves reflexivity. It entails self-reflexivity in that heteronomous monitoring of workers by rules is displaced by selfmonitoring. It involves (and entails) "structural reflexivity" in that the rules and resources (the latter includes the means of production) of the shop floor, no longer controlling workers, become the object of reflection for agency. That is, 
agents can reformulate and use such rules and resources in a variety of combinations in order chronically to innovate.

(Lash in Beck et. al. 1994: 119)

Neither Virno (1996) nor Lash (1994) suggest that this 'reflexivity', this resort to and promotion of a 'general intellect', are homogenous processes, instead they acknowledge the anomalous and paradoxical patterns of 'freisetzung' which produces 'reflexivity winners' and 'losers'

In his theoretical explorations of structure and agency in complex societies, Virno recovers Marx's conception of virtuosic performance, meaning intellectual labour without a recognisable product, a process exemplified by 'performing artists', but which also covers teachers, doctors, priests, barristers and, contemporarily, counsellors, advisors, therapists, direct action trainers and movement facilitators. From Marx's perspective, these virtuosi are special and problematic categories, which are eventually equated with service work, due to their 'non-productive' nature. For Virno (1996), this category has subsequently come to represent much of the 'post-Fordist' organisation of production, where the function of labour:

consists no longer in the carrying out of a single particular objective, but in the modulating (as well as the varying and intensifying) of social cooperation'; whereby the process of production mimics the experience of activism (poiesis and praxis) through variations on a theme he describes as a 'parody of selfrealization...[which] represents the true acme of subjugation

(1996: 193)

This leads Virno (1996) to theorise the possibility of collective action that is subversive to capitalist relations of production, through the annexation of a 'general intellect', defined in the broadest sense as a 'public resource' (faculty of language, ability to learn, abstract, correlate and reflect in an information orientated context) to a political community, in a non-State public sphere. When unpacked, this is taken to mean that in order for collective action to assume an antagonist orientation, one would expect the precursors of the manifestation of that action to be politicised, reflexive community of activists acting within global civil society. This is precisely the context in which the AGM has emerged over the past ten to fifteen years.

Thus, Virno defines exodus as ultimately involving 'defection from the state, the alliance between general intellect and political action, and a movement towards the public sphere of intellect.' (Virno 1996: 197). Intemperance, for Virno (1996), is the cardinal virtue of exodus; as it represents a nonservile virtuosity that transforms civil disobedience - 'the sine qua non of political action' (1996: 197) - from a liberal construct premised upon the assumption of obedience to the state, to a radical position of fundamental opposition to state forms. A refrain that is echoed amongst social movement networks:

Is taking direct action our way of being heard by, and asking favours from, the policy makers because we are not represented properly in parliament? Is this what we're doing? Or is direct action an attempt to form communities of resistance in a global anti-capitalist struggle: to create a world fit for our desires - one free of hierarchy, exploitation and oppressions? If direct action is about 
anything at all, it's about taking power away from the politicians and bureaucrats and seizing control of our own lives.

This intemperance resonates with Melucci's notion of antagonism and indeed, they are both process-orientated analytical categories denoting 'a complex ensemble of positive actions' (Virno 1996: 198) and involving 'a magma of empirical components' (Melucci 1996: 38). According to Virno (1996), intemperance leads exactly to the position portrayed in the quote above. Where capital is progressively freed from spatial-temporal constraints, representative democracy is equated with the restriction of democracy per se:

The States of the developed West are today characterized by a political nonrepresentability of the post-Fordist workforce. In fact they gain strength from it, drawing from it a paradoxical legitimation for their authoritarian restructuring.

(Virno 1996: 202)

Whilst informational modes of production produce a degree of autonomy that creates ambivalence in the operation and diffusion of power through normative systems of control:

Capitalist power in its post-Fordist stage discovers that it must control a set of organizational dynamics that progressively eludes its grasp. The introduction of psycho-social techniques of intervention in interpersonal relationships and the management's growing interest in analysis of organizational systems reveal within the organization a set of relationships governed by autonomous mechanisms and resistant to immediate sub-ordination to dominant interests.

(Melucci 1996: 253)

Consequently, the spaces for collective action are those in which autonomy, defection, and disobedience become repertoires of agency, using the virtuosic skills of activism (poiesis and praxis). Importantly these are spaces in which 'nomads' normatively associated with other 'spaces' - increasingly participate blurring the boundaries between formal political culture and cultural politics. Virno also describes what he terms a 'right to resistance'; this, once again, has similarities with Melucci's (1995: 48, 1996: 73) evocation of the important role that recognition of adversaries plays in the process of identization. Melucci emphasises that if collective action is to avoid atrophying into ritual and banal equivocation an enemy must be located amongst seemingly inchoate interlocutors and that enemy's orchestration of power must be 'revealed' if the collective movement actor is to remain credible within the movement milieu and wider public sphere. Thus Virno argues that exodus involves a reorientation of the 'geometry of hostility' (1996: 204) where engagements between activists, the state and capital are seen as taking place at numerous points of intersection in both cultural and political spheres involving a line of flight. Seen in these terms, conflict is 'asymmetrical', with activists 'evacuating' predictable positions, such as the 'sedentary' positions that became the norm after the upheavals of the 1960s. Established protest repertoires effectively became demonstrations of powerlessness from this perspective (Camatte 1973). Thus Virno (1996: 205) argues that effective antagonistic action involves a war opened on many fronts; social movements and contentious collective actors need to flee from 
engagements defined by their opposition, reappearing on terrain they have chosen, to confuse and blind their 'enemy' viii.

\section{Conclusion: A Post-Representational Turn in Social Movement Studies?}

Despite what has come to be known as the 'cultural turn' in social movement studies (Poletta 2004, 2001; Johnston and Klandermans 1995) with its focus upon identity, (Melucci, 1996) framing (Snow et. al, 1996, Snow \& Benford, 1988, Chesters \& Welsh, 2004) and the 'politics of signification' (Benford and Snow 2000: 613), the negotiation of global encounters between diverse movements and their mobilisations around trade, development and social justice continue to be theorised using familiar positivist and structuralist concepts most of which are reliant upon an explanation of 'scale shift' (Tarrow, 2005) that emphasises the supposed continuity of mobilisation and political opportunity structures from the national to the transnational scale. Even amongst culturalist interventions, including those researching emotion, affect and meaning (Goodwin and Jasper, 2004, Polleta, 2004), the preoccupation of social movement theory with causal and explanatory variables means there is the presumption that the utility of these 'alternative' approaches remains their ability to account for mobilisation, which is addressed as if it were the only analytical 'problem' of social movement research. Meaning-making within movements is respected and attended to, but not because of its potential to create critical subjectivities, challenge existing 'expert' knowledges, or access immanent possibilities of social organisation. But because it is considered rightly, but reductively, as instrumental to mobilisation, which is then further reduced to being representative of a collective (minority) identity or as indicative of a political claim or grievance. The powerful critiques of representation and the knowledge-practices within global movements that seek to overcome these by creatively and generatively working with difference and complexity are largely ignored.

In some small way then, our theoretical excurses in to the theory of Exodus reminds us of the folding of agency, theory and philosophy in knowledge practices that are thought-through action within social movement networks. It hopes to frame and explain possibilities immanent to informationalised capitalism and the subsequent post-Fordist reorganisation of the labour process and it describes the complex effects of the alter-globalisation movements as they deterritorialise important elements of the social and political field. It is both of and about the process of 'becomingrevolutionary' and as such, it illustrates the recursive structuration in complex social systems by positive feedback mechanisms. It also exhibits the importance of concepts in the creation of new ways of looking, in new ways of seeking correspondences between the potential theorised and the artisanal process of discovering singularities through the movements' practice.

The alter-globalisation movements proceed through a cultural politics (Jordan \& Weedon 1995, Osterweil 2004) that questions the reification of the political as the preserve of structures, institutions and frameworks that are separate from, or exclude the everyday. This is a familiar trajectory in the 'south' where Alvarez argues 'all social movements enact a cultural politics' (Alvarez et. al. 1998: 6), thus supporting de Sousa Santos (2003) who suggests that plateaux such as the WSF, constitute an 'epistemology of the south' simultaneously averse to the techno-scientific rationality of western modernity but conducive to a 'sociology of emergences'. 
Complimenting this 'southern epistemology' is the return in the 'north' of the aesthetic and the affective through multiple repertoires of creative action and autonomous cultural production. Such an aesthetic has deep roots in radical art practices, such as Dada, the surrealists and the Situationist International (SI 2003, Jappe 1999) and was a strong feature of the sixties movements. Jerry Rubin, a US activist/author of that period described it in the following terms, 'Life is a theatre and we are the guerrillas attacking the shrines of authority... The street is the stage. You are the star of the show and everything we're taught is up for grabs' (cited in Stephens 1998: 97). The end of post-World War II bi-polar geo-politics has been accompanied by a resurgence in the performative appropriation of public spaces for the enactment of critical messages.

Such repertoires were part of the transition to globalisation. Poland's 'Orange Alternative', a colour distinct from both socialist red and Papal yellow, engaged in an extended communal party deploying street theatre and iconic acts such as banner drops, making Orange Alternative a focal point of conversation across Poland. In Wroclaw there were no factory occupations mirroring Solidarity actions because 'We had the streets, so we did'nt need to strike'. (Kenny 2002: 224). These forms of action erupted across Europe, the Americas, Australia as the global south burned GM crops, resisted deforestation and occupied factories with the AGM serving as a network of networks capable of holding these vectors in tension as an increasingly complex parallelogram of forces

Elsewhere, 'Tactical Frivolity', 'radical cheerleaders', the 'Yes Men', the 'Laboratory of Insurrectionary Imagination' and countless other imaginative, aesthetic, affective and self-organising groups have proliferated. The apparently marginal, defiantly subversive and profoundly internationalist character of such practices enables them to escape easy assimilation. Consequently, the play of these lines as vectors of force and flight allows questions about the boundaries of art, politics and culture under neoliberal globalisation to be re-thought and reframed. The planeterization of these tendencies, the epistemology of thinking-through action and the return of a radical aesthetic within the AGM expressed through the parallelogram of forces marks a return to desire as becoming, to the affective, to rhythms of speech, music, and modes of movement as important political terrain. This extends movement repertoires of connectivity into new assemblages that strive to maintain open boundary conditions and thus continue to find different and other registers of antagonistic expression. Leading the Zapatistas to argue that:

The revolution in general is no longer imagined according to socialist patterns of realism, that is, as men and women stoically marching behind a red, waving flag towards a luminous future: rather it has become a sort of carnival.

(Subcommandante Marcos cited in Rachenburg E. \& Heau-Lambert C. 1998)

The self-conscious adoption by the alter-globalisation movements of artistic modes of expression, from carnival to movement refrains and 'rhythms of resistance', helps constitute a complex ontology of signification. Therefore, as we have repeatedly argued it remains inaccessible to social movement models of political exchange that operate within the conceptual confines of the nation state and frame analyses focussing on collective identity as a mechanism of expressing political claims or grievances. This dwelling in the cultural and the manipulation of codes 
and behaviours is a well worn line of flight for network actors in social movement networks, it marks an exodus from the 'political', from institutionalised assimilation and mechanisms of capture and reaffirms the importance of factors otherwise downplayed in politics as usual. 


\section{Bibliography}

Althusser, L. (1962) For Marx, London: Penguin.

Alvarez, S. (2000) 'Translating the Global: Effects of Transnational Organizing on Latin American Feminist Discourses and Practices.' Meridians: A Journal of Feminisms, Race, Transnationalism, 1, 1: 29-67.

Alvarez, S.E., Dagnino, E., \& Escobar, A. (eds.) (1998) Cultures of Politics, Politics of Cultures: Re-visioning Latin American Social Movements, Boulder: Westview Press.

Appiah, K. A. (1992) In My Father's House, Oxford: Oxford University Press.

Arendt, H. (1958) The Human Condition, Chicago: University of Chicago Press.

Barabasi, A-L. (2002) Linked: The New Science of Networks, Cambridge, MA: Perseus.

Bateson, G. (1973) Steps to an Ecology of Mind, London: Paladin.

Beck, U., Giddens, A., and Lash, S. (1994) Reflexive Modernization: Politics, Tradition and Aesthetics in the Modern Social Order, Cambridge: Polity Press.

Bell, D. (1973) The Coming of Post-Industrial Society, New York: Basic Books.

Benford, R. \& Snow, D. (2000) 'Framing Processes and Social Movements: An Overview and Assessment' Annual Review of Sociology, 26: 611-639.

Bensaid, D. (2002) Marx for our Times, London: Verso.

Berg, J.C. (ed.) (2002) Teamsters and Turtles: U.S. Progressive Political Movements in the $21^{\text {st }}$ Century, Colorado: Rowman and Littlefield.

Bogue, R. (2004) Deleuze's Wake: Tributes and Tributaries, New York: State University of New York Press.

Bonta, M. \& Protevi, J. (2004) Deleuze and Geophilosophy, Edinburgh: Edinburgh University Press.

Bouchard, D.F. Ed. (1977) language counter-memory and practice: selected essays and interviews by Michel Foucault, Ithica, Cornell University Press.

Bruce, I (ed.) (2004) The Porto Alegre Alternative: Direct Democracy in Action, London: Pluto Press.

Buchanan, M. (2002) Small World: Uncovering Nature's Hidden Networks, London: Wedenfeld Nicholson. 
Butler, J. \& Scott, J. (eds.) (1992) Feminists Theorize the Political, New York: Routledge.

Camatte, J. (1973) Against Domestication (pamphlet), Ontario: Falling Sky Books.

Castells, M. (1996) The Rise of the Network Society, Vol. 1, The Information Age: Economy, Society and Culture, Oxford: Blackwell.

Castells, M. (1997) The Power of Identity, Vol. 2 of The Information Age: Economy, Society and Culture, Oxford: Blackwell.

Castells, M. (2000) Information technology and Global Capitalism, In: Hutton, W., and Giddens, A. (eds.) Global Capitalism, New York: The New Press, pp. 52-74.

Chesters, G. (2004a) 'Complexity Theory. In Ritzer, G. (ed.) Encyclopedia of Social Theory, London: Sage, pp. 125-127.

Chesters, G. (2004b) 'Global Complexity and Global Civil Society', Voluntas: The International Journal of Voluntary and Non-Profit Organizations, 15, 4: 323-342.

Chesters, G., and Welsh I. (2004) 'Rebel colours: "Framing" in global social movements', Sociological Review 53, 3: 314-335.

Chesters, G., and Welsh I. (2005) 'Complexity and Social Movement: Process and Emergence in Planetary Action Systems' Theory, Culture and Society, 22, 5: 187211.

Chesters, G., and Welsh I. (2006) Complexity and Social Movements: Multitudes at the Edge of Chaos, London: Routledge.

De Sousa Santos, B. (2003) 'The World Social Forum Towards a Counter Hegemonic Globalization' Presented at the XXIV International Congress of the Latin American Studies Association, Dallas, 27-27 March. Online. Available: < http://www.duke.edu/\%7Ewmignolo/publications/pubboa.html > (Accessed March 25th, 2005).

Delanda, M. (1997) A Thousand Years of Nonlinear History, New York: Swerve.

Delanda, M. (2002) Intensive Science and Virtual Philosophy, London: Continuum.

Deleuze, G. (1992) 'Postscript on the Societies of Control' October, 59: 3-7. Online. Available: < http://www.n5m.org/n5m2/media/texts/deleuze.htm>

Deleuze, G. (1994) Difference and Repetition, New York: Columbia University Press.

Deleuze, G. \& Guattari, F. (2002) A Thousand Plateaus, 4th edn, London: Continuum. 
Deleuze, G. \& Parnet, C. (2002) Dialogues II, 2nd edn, London: Athlone.

Diani, M. (1992) 'The Concept of Social Movement', Sociological Review, 40,1:125.

Diani, M. \& Della Porta, D. (1998) Social Movements: An Introduction, Blackwell: Oxford.

Eco, U. (1986) Faith in Fakes, London: Secker \& Warburg.

Engels, F. (1955) Anti-Dühring London: Lawrence \& Wishart.

Eve, R.A. Horsfall, S. Lee, M.E. (1997) Chaos, Complexity \& Sociology: Myths, Models and Theories, London: Sage.

Featherstone, M. (1991) Consumer Culture and Postmodernism, London: Sage.

Fisher, W. F., and Ponniah, T. (eds.) (2003) Another World Is Possible: Popular Alternatives to Globalization at the World Social Forum, London: Zed.

Foucault, M. (1975) Birth of the Clinic. London: Tavistock.

Foucault, M. (1977) Discipline and Punish. London: Penguin.

Foucault, M. (1977a) Language, Counter-memory and Practice: Selected Essays and Interviews, edited by Bouchard, D. F., Ithaca: Cornell University Press.

Foucault, M. (1979) The History of Sexuality. . London: Penguin.

Gamson, W.A. (1995) 'Constructing Social Protest'in Johnston, H. \& Klandermans, B. Eds. Social Movements and Culture, London: UCL Press.

Goffman, E. (1974/1986) Frame Analysis: an essay on the organization of experience, Boston: Northeastern Press.

Goodwin, J., Jasper, J., \& Polleta, F. (eds.) (2001) Passionate Politics: Emotions and Social Movements, Chicago: University of Chicago Press.

Granovetter, M. S. (1973) 'The strength of weak ties' American Journal of Sociology 78, 6: 1360-1380.

Guattari, F. (2000) The Three Ecologies. London: Athlone Press.

Haraway, D. (1989) Primate Visions, New York: Routledge.

Haraway, D. (1999) 'A Cyborg Manifesto: Science Technology and Socialist Feminism in the Late Twentieth Century', in. Hopkins, P.D. (ed). Sex/Machine: Readings in Culture, Gender and Technology, Bloomington: Indiana University Press. 
Hardt, M. (1995) 'The withering of civil society' Social Text 45: 27-44.

Hardt, M., \& Negri, A. (2000) Empire, Cambridge, MA: Harvard University Press.

Hardt, M. (2002) 'Today’s Bandung?,' New Left Review, 14, 112-118.

Hardt, M., \& Negri, A. (2003) 'Forward' in: Fisher, W. F., and Ponniah, T. (eds.) Another World Is Possible: Popular Alternatives to Globalization at the World Social Forum, London: Zed, pp. xvi-xix.

Hardt, M., \& Negri, A. (2004) Multitude: War and Democracy in the Age of Empire, New York: Penguin.

Hetherington, K. (1998) Expressions of Identity: Space, Performance, Politics, London: Sage.

Holloway, J., and Pelaez, E. (1998) (eds.) Zapatista! Reinventing Revolution in Mexico, London: Pluto Press.

Hooks, B. (1981) Ain't I a Woman, Boston: South End Press.

Jappe, A. (1999) Guy Debord, $3^{\text {rd }}$ edn. Berkeley and Los Angeles: University of California Press.

Johnston, H. \& Klandermans, H. (1995) Social Movements and Culture, London: Routledge.

Jordan, J. (1998) 'The art of necessity: the subversive imagination of anti-road protest and Reclaim the Streets', in McKay, (ed.) DIY Culture: Parties and Protest in Nineties Britain, London: Verso.

Jordan, G. and Weedon, C. (1995) Cultural Politics, Class Gender, Race and the Postmodern World, London: Blackwell.

Kenney, P. (2002) A Carnival of Revolution, Oxford \& Princeton: Princeton University Press.

Klein, N. (2000) No Logo, London: Flamingo.

Lash, S. (1990) 'Learning from Leipzig', Theory Culture and Society, 7,4,145-158.

Lash, S. (1994) Reflexivity and its Doubles: Structure, Aesthetics, Community, in Beck, U., Giddens, A., \& Lash, S., Reflexive Modernization: Politics, Tradition and Aesthetics in the Modern Social Order, Cambridge: Polity Press.

Lash, S., \& Urry, J. (1994) Economies of Signs and Space, London: Sage. Lotringer, S. \& Marazzi, M. (1980) Italy: Autonomia: Post-Political Politics, New York: Semiotext(e). 
Lotringer, S. (2004) 'Foreward' in Virno, P. (2004) A Grammar of the Multitude, New York/Los Angeles: Semiotext(e).

McAdam, D., Tarrow, S. \& Tilly, C. (2001) Dynamics of Contention, Cambridge: Cambridge University Press.

McDonald, K. (2002) 'From Solidarity to Fluidarity: social movements beyond 'collective identity' - the case of globalization conflicts', Social Movement Studies 1 (2): 109-128.

McDonald, K. (2006) Global Movements: Action and Culture, Oxford: Blackwells.

Maffesoli, M. (1995) The Time of the Tribes, Sage, London.

Marcos, Subcommandante (2001). Our Word is Our Weapon, New York: Seven Stories Press.

Massumi, B. (1992) A User's Guide to Capitalism and Schizophrenia, Cambridge, MA: MIT Press.

Melucci, A. (1989) Nomads of the Present, London: Radius Hutchinson.

Melucci, A. (1996) Challenging Codes: Collective Action in the Information Age, Cambridge: Cambridge University Press.

Notes from Nowhere (eds.) (2003) We Are Everywhere: The Irresistible Rise of Global Anticapitalism, London: Verso.

Osterweil, M. (2004) 'A cultural-political approach to reinventing the political' International Social Science Journal. 56 (182): 495-506.

Patton, P. (2000) Deleuze and the Political. London: Routledge.

Polleta, F. (2004) Freedom is an Endless Meeting: Democracy in American social Movements, Chicago: University of Chicago Press.

Protevi, J. (2001) Political Physics, London: Athlone Press.

Rajchenburg, E. \& Héau-Lambert, C. (1998) 'History and Symbolism in the Zapatista Movement' in Holloway, J. \& Peleáz, E. (eds.), Zapatista: Reinventing Revolution in Mexico, London: Pluto Press.

Rutherford, J. (ed.) (1990) Identity, Community, Culture, Difference, London: Lawrence and Wishart.

Snow, D. Rochford, B., Worden, S. and Benford, R. (1986) 'Frame Alignment Processes, Micromobilization and Movement Participation', American Sociology Review, 51:464-81.

Snow, D. \& Benford, R. (1988) Ideology, Frame Resonance and Participant Mobilization, in Klandermans, B. Kriesi, H. \& Tarrow, S. (eds.) From Structure to Action: Comparing Social Movement Research Across Cultures, International Social 
Movement Research, 1, Greenwich, Conneticut: JAI.

Stephens, J. (1998) Sixties Radicalism and Postmodernism, Cambridge: Cambridge University Press.

Tarrow, S. (1998) Power in Movement: Social Movements and Contentious Politics, Cambridge: Cambridge University Press.

Tarrow, S. (2005) The New Transnational Activism, Cambridge: CUP.

Thrift, N. (1999) 'The Place of Complexity' Theory Culture and Society, 16,3, 3169.

Thrift, N. (2006) Non-representational Theory, London: Routledge

Tormey, S. (2006) "Not in my Name": Deleuze, Zapatismo and the Critique of Representation', Parliamentary Affairs, 59, 1, 1-17.

Touraine, T. (1971) The Post-Industrial Society, London: Wildwood House.

Touraine, A. (1981) The Voice and the Eye, Cambridge: Cambridge University Press.

Tronti, M. (1966) Operai e Capitale ('Workers and Capital'), Turin: Einaudi.

Urry, J. (2000) Sociology Beyond Societies: Mobilities for the Twenty-First Century, London: Routledge.

Urry, J. (2003) Global Complexity, London: Routledge.

Viano, M. \& Binetti, V. (1996) 'What Is to Be Done? Marxism and Academia', in Makalisi, S. et al (eds.), Marxism Beyond Marxism, New York: Routledge.

Virno, P. (1996) 'Virtuosity and Revolution: The Political Theory of Exodus', in Virno, P. \& Hardt, M. (eds.) Radical Thought in Italy: A Potential Politics, Minneapolis: University of Minnesota Press.

Virno, P. (2004) A Grammar of the Multitude, New York/Los Angeles: Semiotext(e).

Wark, M. (2004) Hacker Manifesto. Cambridge, MA: Harvard University Press.

Watts, D. J., and Strogatz, S. H. (1998) 'Collective Dynamics of "Small World" Networks' Nature 393: 440-442.

Welsh, I. (2002) 'Where do movement frames come from? Insights from S26 and global "anti-capitalist" mobilisations', Manchester: Proceedings 8th Alternative Futures and Popular Protest Conference, Vol. 2, April 2-4, Manchester Metropolitan University.

Welsh, I. (2004) 'Network Movement in the Czech Republic: Peturbating Prague', Journal of European Area Studies, 12,3, 321-337. 
Wittel, A. (2001) 'Towards a network sociality', Theory, Culture and Society 18: 3150 .

\author{
Wright, S. (2002) Storming Heaven: Class Composition and Struggle in Italian \\ Autonomist Marxism, London: Pluto Press.
}

\begin{abstract}
${ }^{\mathrm{i}}$ The concept of a digital commons is closely associated with the free software movement, however it is used here in a broader sense to include the patterns of information/knowledge exchange within activist milieu that are mediated by digital technologies.

ii This is a description proffered to the author by a Dutch activist from People's Global Action.

iii The public relations use of this strategy is evidenced by the U.S. suggestion that the anti-debt campaigner and rock star Bono be made Head of the World Bank, see Borger, J. 'Bono's Next No 1 Might be at World Bank' The Guardian, March 7, 2005. This appears to have been part of a PR 'spin' to pre-empt/distract from the appointment of a key U.S. neo-conservative - Paul Wolfowitz to this post. As U.S. Defence Secretary Wolfowitz was one of the architects of the war against Iraq in 2003.

iv Properties that are evident at the systemic level but which are not implicit within the elements comprising the system or through the addition of those elements or the relations between them.

' There are similarities here to Castells' (1997:8) identification of 'project identities' in the 'network society', which he defines as coming into being when 'social actors, on the basis of whichever cultural materials are available to them, build a new identity that redefines their position in society and, by doing so, seek the transformation of overall social structure.'

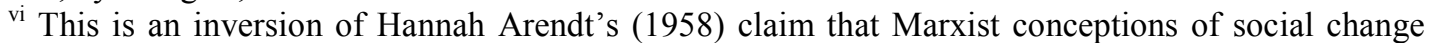
have been predicated upon forms of social organisation that rely upon the concept of work, as synonymous with a process of making a product. Thus, Arendt (1958) claimed that notions of political activity came to be seen as having a 'product' - history, the state, the party and so forth.

vii This leads Lash to ask the rhetorical question '... just how much freedom from the "necessity of structure" and structural poverty does (a) ghetto mother have to self-construct her own "life narratives"?' (1995:120).

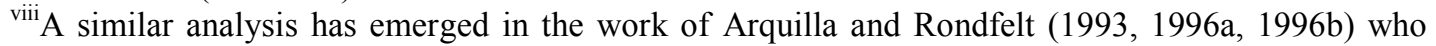
have been working for the RAND Corporation on theorising the strategic implications for the United States government, of what they have termed 'social netwar' - the capacity of civil society to mobilise solidarity networks, to take collective action and to facilitate their organisation through communications technology.

${ }^{\text {ix }}$ Rhythms of Resistance is the name of a international collective of musicians and dancers that play during anti-capitalist protests - $\underline{w w w . R h y t h m s o f R e s i s t a n c e . c o . u k}$. Frequently referred to as a 'Samba Band' their roots are 'closer to the Afro Bloc parading drum bands that emerged in the mid $70 \mathrm{~s}$ in Salvadore, Bahia in Brazil.' The outcome of such rhythmic interventions is to introduce an affective and ambiguous dimension to the space of protest, which marks the becoming-Carnivalesque of that space. The use of musical metaphors - 'ritornellos', 'refrains' etc as a means of illustrating the complex and dynamical interplay between action, agency, affect and sensation is prominent in Deleuze (1994) and Deleuze and Guattari (2002). See also Buchanan \& Swiboda, (2004).
\end{abstract}

